UDC 621.791 .3

DOI 10.36910/6775-2313-5352-2020-17-24

Chuiko M.M., Ph.D., Zavalskii V.I., master

Ivano-Frankivsk National Technical University of Oil and Gas

\title{
THE CONTACT ANGLE CONTROL OF THE SOLDER FOR IMPROVING THE SOLDERING QUALITY
}

High quality of the soldering process can be achieved with the right choice of the necessary soldering materials. Since wetting determines the further nature of the connection between the solder and the main soldering material, the contact angle measurement is the basis for quality control of soldering materials, provided that the basic requirements of the technological process. The determination of the contact angle value is carried out by the indirect method of the sessile drop, by measuring the basic parameters of the drop using infrared transducer. A smaller value of the contact angle corresponds to a better interaction of materials, and hence a better electrical contact

Keywords: solder, wetting, contact angle, control, quality.

Introduction. At present, there are virtually no electrical devices or appliances that do not use the soldering process to connect certain parts, elements, or individual blocks. This connection type allows to fasten both small SMD parts and more massive output components.

Since in practice soldering is carried out using methods that speed up the soldering process (wave soldering, immersion, etc.), the installation quality of elements on the board strongly depends on the correct choice of necessary solders and fluxes to ensure good solder spreading on the conductors and reliable electrical contact between the elements and the board. Fluxes are used to remove oxides and contaminants from the metal surface, protect it from oxidation and better wet the solder. All this helps to increase the solder wetting properties and, as a consequence, improve the soldering quality.

Presentation of the main material. Solder - the metal or alloy, applied to connection of metal, ceramic and other details. The most important properties of solders are high adhesion and capillary properties and high fluidity. The service life of the soldered joint depends on the soldering technology correctness and the parameters of the environment in operation process.

In each case, the solder is selected depending on:

- properties of materials from which the combined parts are made;

- permissible melting point;

- sizes of details;

- requirements for the necessary quality of the joint (its mechanical strength, corrosion resistance, electrical conductivity, durability and total cost), the soldering method and soldering technological conditions.

Solders are divided into "Soft solders" and "Hard solders" [1].

The group of soft solders with a melting temperature range from 90 to $450{ }^{\circ} \mathrm{C}$ is used for everyday use.

The most popular solders of this class are POS-60 (60/40, Tin / Lead, Sn / Pb), which melts at $188^{\circ} \mathrm{C}$, and POS-63 (63/37, Sn / Pb), lead [3]. It is used mainly in electronics and electrical engineering. It has a low and clear melting point $-183^{\circ} \mathrm{C}$. This solder is used for soldering electrical circuits. The addition of tin, which is a more expensive material than lead, improves the solder alloy wetting properties, and as the tin content increases, the tensile strength increases. It is used for chips, boards, units of high-frequency and measuring devices. It should be noted the electrical resistivity of lead solders is 8-9 times greater than that of copper.

It should also be added that Directive 2002/96 / EC of the European Parliament on waste electrical and electronic equipment (WEEE) entered into force on 27 January 2003. The modern electronics industry has faced the fact of organizing the collection and disposal of waste containing heavy metals and flame retardants. To successfully solve this problem, one of the necessary conditions is the transition to lead-free technology for the electronic equipment manufacture - technology using materials that do not contain lead.

Lead-free solders are solders that are designed to replace low-melting solders based on lead and may contain: tin, copper, silver, bismuth, indium, zinc, antimony and small amounts of other metals. 
Lead-free solders are used to replace tin and lead solders ideally have the same properties as lead-tin solders. Most lead-free tin-based solders contain silver, copper and other additives. Elements doped in lead-free solders help to improve the properties of pure tin so that the solder based on them becomes more favorable for electrical products. For the electronics industry, the most acceptable solders for replacing traditional alloys Sn63P37 and Sn62P36Ag2 - Sn95, 5AgC, 8Cu0, suitable for soldering by melting (in a paste) and for wave soldering.

However, lead-free solders have a number of disadvantages:

- melting point is higher by $5-20^{\circ} \mathrm{C}$;

- due to the first problem the cost increases. It becomes necessary to use more heat-resistant materials;

- usually have worse wettability. You need to use more chemically active fluxes, which carries additional risks.

If the temperature is higher than $450^{\circ} \mathrm{C}$ - the solders are called solid, and according to the melting point are divided into: medium melting (from 450 to $1100^{\circ} \mathrm{C}$ ); high-melting (from 1100 to $1850^{\circ} \mathrm{C}$ ) and refractory (over $1850^{\circ} \mathrm{C}$ ) [2].

Copper-phosphorus and copper-zinc solders (PMC-36 and PMC-54) are widely used. They are well suited for fastening parts for which static loads are provided. Copper-phosphorus solders include alloys of copper, tin with phosphorus additives. This solders are used for soldering copper, copper alloys, silver, cast iron, hard alloys. Zinc-brazed solders are used for soldering steels and alloys that have increased melting points. These include bronze, brass and a number of other materials.

The soldering with these solders requires a high temperature and therefore mostly use the methods of electro-contact soldering, in which the connected parts are clamped between the carbon electrodes then a large current is passed through them. Gas welding machines, eddy current induction melting devices and, in some cases, blowtorches can also be used.

The wetting process is the first stage of physicochemical interaction of the solder with the base metal. The result of it is the establishment of interatomic bonds between them and the solder spreading on the metal surface with a finite contact angle (CA).

The spreading of solder can have several mechanisms: surface diffusion of solder atoms, evaporation followed by condensation of solder atoms or particles, the movement of relatively thick layers (phase spreading), dissolution, bulk diffusion [1,2]. The mechanisms and results of the interaction between the parent metal and the solder are determined by the electronic configurations of their atoms. In the wetting process the base metal and the solder spreading, the two free surfaces are replaced by one interfacial surface with a lower free energy of the system.

Therefore, to successfully perform the soldering process, solders must wet the base metal, spread over its surface and fill gaps (cracks). These processes may be accompanied by significant dissolution of the parent metal in the solder and mutual diffusion.

Moreover, the better the wetting of the base material, the stronger the connection, the better the electrical contact of the connecting parts and the better the quality of soldering as a whole, subject to the requirements of the technological process (temperature, soldering time, absence of surface contaminants and slags and other).

Therefore, it can be argued that the main determining parameter of elements quality connection by means of the soldering process is the high wettability of the elements by solder. The amount of wetting can be estimated by the value of the CA $\theta$, which is determined quite experimentally. In this case, we propose to determine the solder $\mathrm{CA}$ of the base material according to the main parameters of the sessile drop (height and diameter) based on the formula [3,4]:

$$
\operatorname{tg}\left(\frac{\theta}{2}\right)=\frac{h_{d}}{r_{d}}
$$

where $h_{d}$ - drop height, mm;

$r_{d}$ - radius of the contact line "solid - liquid", $\mathrm{mm}$.

Expressing from this formula the CA $\theta$, the calculation formula of this method will take the following form:

$$
\theta=2 \operatorname{arctg}\left(\frac{2 h_{d}}{d_{d}}\right)
$$


We suggest measuring the drop height with the help of infrared (IR) transducers, which will provide infrared wave radiation and registration of reflected waves from the solder surface. The height of the lying drop $h_{d}$ is determined by the formula:

$$
\boldsymbol{h}_{\boldsymbol{d}}=\boldsymbol{h}_{\mathrm{o}}-\boldsymbol{h}_{\boldsymbol{a}},
$$

where $h_{0}$ - the fixed distance from the transducer to the base surface, $\mathrm{mm}$;

$h_{a}-$ the distance from the transducer to the top of the solder drop surface, $\mathrm{mm}$.

In the research process, the IR transducers are placed horizontally above the investigated surface of the solid body at a distance $h_{0}$, it is in our case is $4 \mathrm{~cm}$ (Fig. 1 a).

Since the solder surface is curved, it is necessary to use not one transducer, but several, placed in the form of a matrix over the control object, to fix the reflected beam from this surface. In this case, we propose to use a matrix of IR transducers of size $3 \times 3$ (Fig. $1 \mathrm{~b}$ ). This configuration allows you to determine the value of the maximum height of the drop, for which the time of "return" of the reflected beam is minimal. The calculation of the solder drop height is carried out on the basis of the matrix converter measured values, fixes the minimum distance to the solder surface.

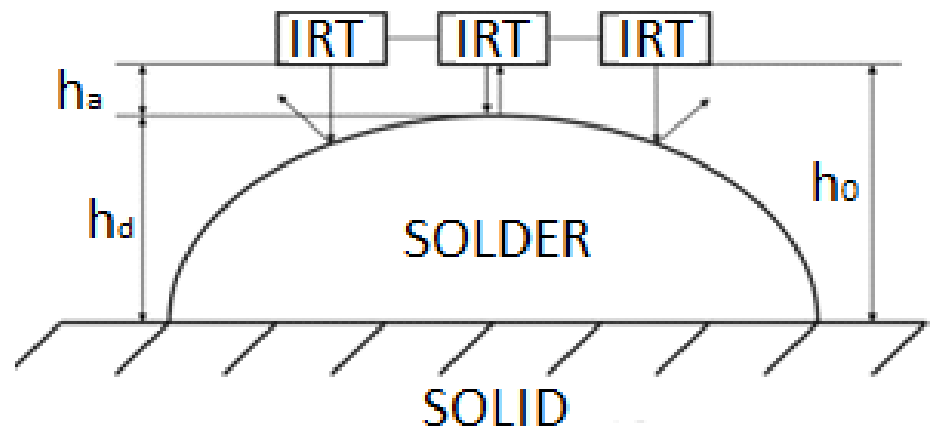

a)

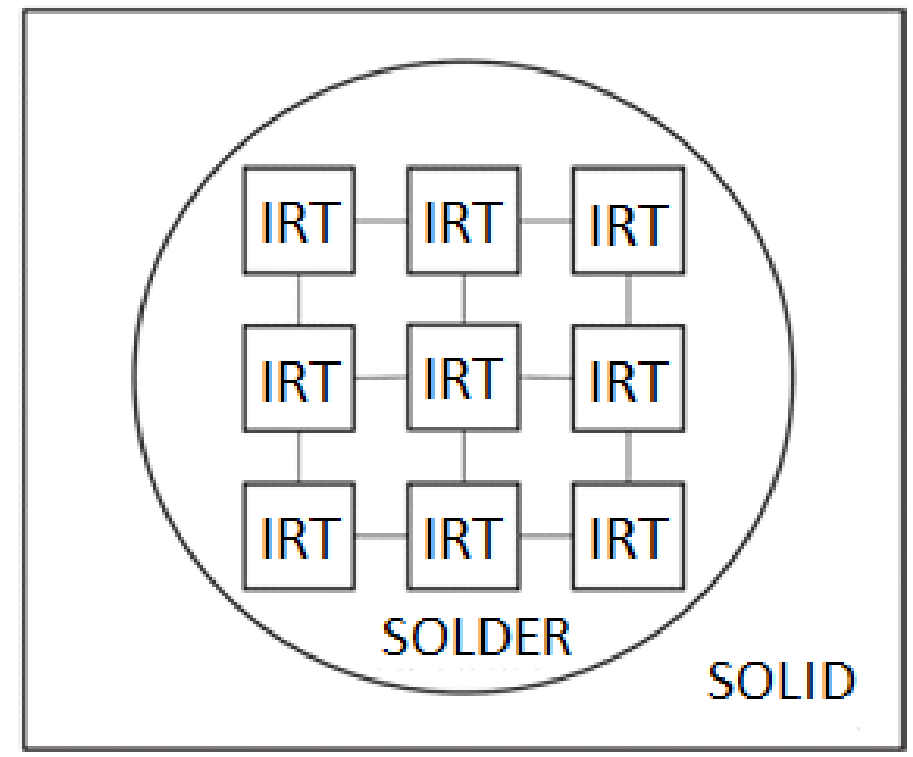

b)

Fig.1. Scheme of a matrix module for determining the solder drop height

The drop diameter is determined using a digital microscope company Shine Vision and reference scale.

To implement the proposed method of soldering materials quality control based on the determination of the contact angle, a device was developed.

The operation principle of the developed device on the basis of infrared transducers is based on a time interval measurement between the radiation moment of a probing IR monopulse (start-pulse) and the reception moment of the radiation reflected from object (stop-pulse). The radiation source in device is a pulsed IR transducer (usually semiconductor). The IR pulse is generated by IR transducer, 
it is located on the matrix module. It is controlled by the control unit of the matrix module. The reflected radiation enters the IR transducer phototransistor and amplified by amplifier. Time interval meter, connected to the clock generator, turned on at the moment of the IR pulse emission by the matrix diode and turned off at the time of the reflected radiation reception by the receiving phototransistor, the signal of it is amplified and issuing a digital code. The synchronization and control unit interprets the code in the height of the solder drop, generates a signal on the indicator, and receives commands from the control unit. Heating of the control object, a sample of the base material with a certain dosed mass of solder controlled by the heater control unit. To ensure the operating temperature of the matrix module in the developed device provides a cooler. It is based on Peltier elements and is controlled by the cooler control unit. The heater and the cooler are fed from the power supply and the measuring circuit elements through a low-voltage voltage regulator

At a constant velocity of electromagnetic radiation spreading in the layer of medium (air), the distance to the object can be calculated using the following expression (taking into account the radiation travels twice the distance) [5]:

$$
L=\frac{c \Delta t}{2 n}
$$

where $c$ - speed of IR radiation in vacuum, $\mathrm{m} / \mathrm{s}$;

$\Delta t$ - the time interval between the moments of sending and receiving radiation of the probing pulse, $\mathrm{s}$; $n$-refractive index of the propagation medium for the used wavelength of radiation (for air $n=1$ ).

At present, there is a huge variety of different factory infrared (IR) LEDs [6]. To determine the $\mathrm{CA}$, it is necessary to ensure the minimum dimensions of the measuring unit to ensure the required measurement accuracy, due to the small size of the sample object control. Therefore, as a primary transducer, a selected reflective optical sensor with transistor output VCNT2020 is selected, allows to emit and receive IR oscillations of a certain length. The proposed transducer from Vishay Intertechnology in a minimalist SMD format [7], has a compact design $2.5 \times 2 \times 0.8(\mathrm{~mm})$, where the IR source and receiver are assembled in one housing. The working infrared wavelength is $940 \mathrm{~nm}$. The receiver is made of an IR silicon phototransistor. In this sensor, the analog signal (photocurrent) is caused by the IR radiation reflected from the object.

The sensor is protected by an IR filter, it protects well from ambient light and thus increases the ratio of useful signal to noise.

The scheme of the matrix is collected on this transducers is given on (fig. 2) 


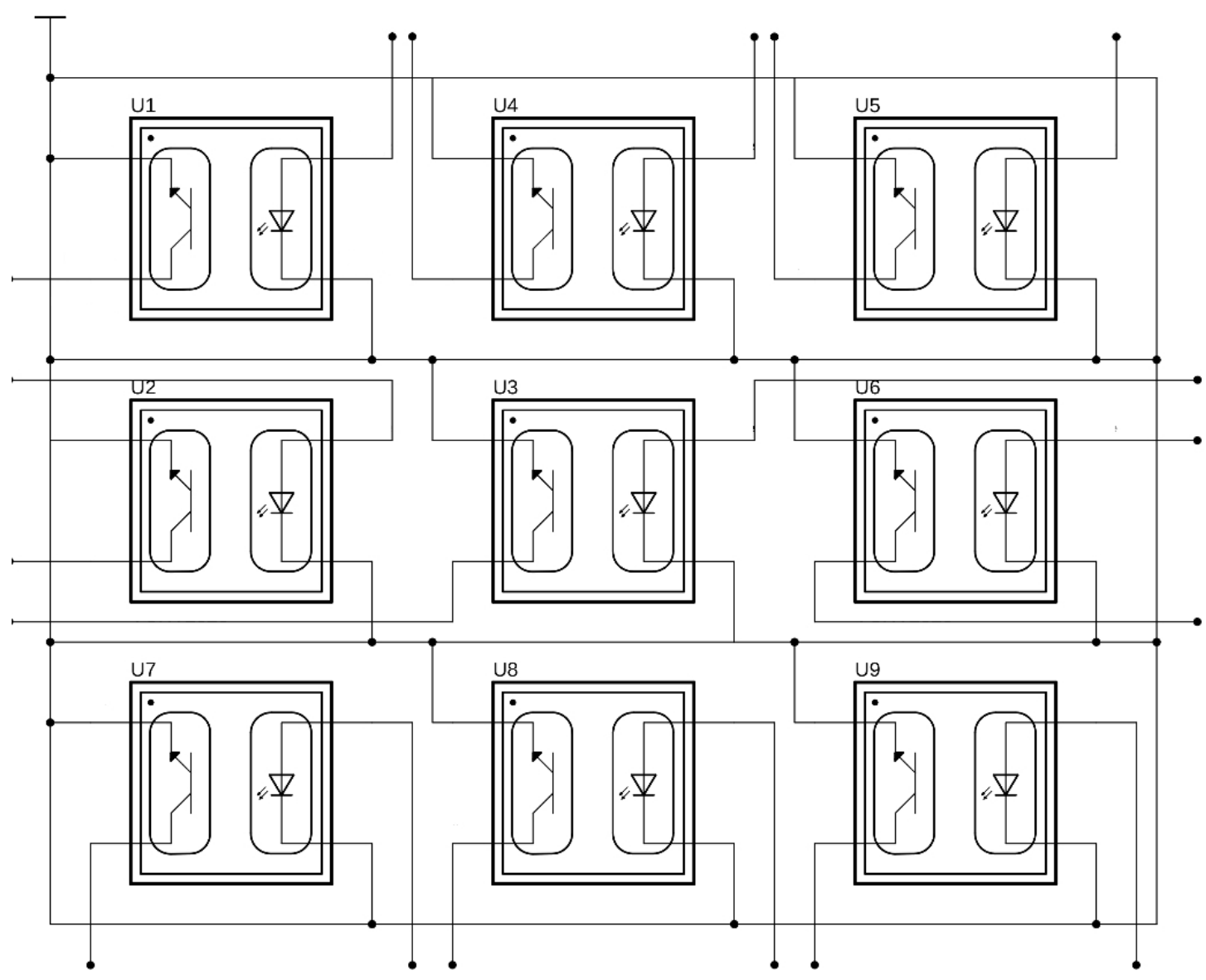

Fig. 2. Matrix module of IR transducers

For hardware and software implementation of measurement results calculations by matrix module is suggested to use open Arduino hardware. Using this platform makes it possible to increase efficiency of the developed device as many modules for signal processing and digitization are already available that will save developers a lot of time.

Direct digitization and signal processing will be performed by the ARDUINO UNO REV3 mock-up board [8]. It is a microcontroller board based on ATmega328P. It has 14 digital I / O pins (6 of which can be used as a PWM output), 6 analog inputs, a $16 \mathrm{MHz}$ quartz crystal, a USB connection, a power connector, ICSP and a reset button. The board contains everything you need to support the microcontroller; just connect it to your computer with a USB cable or to an AC adapter or battery.

Conclusions. A wide range of soldering materials allows the selection of solder with optimal properties that provide high wettability and strength of the mechanical connection of parts. The use of an infrared transducer for the solder quality control allows to obtain a measuring signal in a digital code form. It is interpreted in the solder drop height, on the basis of which the solder CA is determined. A smaller value of the wetting angle corresponds to a better interaction of materials, and hence a better result of the soldering process.

\section{Information sources}

1. Паяння. Методичні вказівки до виконання лабораторних робіт для студентів спеціальності 7.05050403 «Відновлення та підвищення зносостійкості деталей і конструкцій»/ Уклад.: В.В. Квасницький, Д.В. Степанов, І.Л. Левченко - К: 2015. - 57 с.

2. Паяння металів. Дослідження фізико-хімічних процесів та технологічних факторів при паянні / В.В. Квасницький, В.Ф. Квасницький, Б.В. Бугаєнко, Г.В. Срмолаєв; під редакцією В.Ф. Квасницького. - Миколаїв: НУК, 2006. - 160 с.

3. Адамсон А. Физическая химия поверхностей: Пер. с. англ./Под ред. 3. М. Зорина, В. М. Муллера. - М.: Мир., 1979. - 568c.

4. Зимон А.Д. Адгезия жидкости и смачивание. Москва : Химия, 1974. 416 с. 
5. Лазерные приборы и методы измерения дальности : учеб. пособие / В.Б. Бокшанский, Д.А. Бондаренко, М.В. Вязовых, И.В. Животовский, А.А. Сахаров, В.П. Семенков ; под ред. В.Е. Карасика. - М.: Изд-во МГТУ им. Н.Э. Баумана, 2012. - 92 с.

6. Світлодіоди: фізика, технологія, застосування: навч. Посібник / В. І. Карась, Л. А. Назаренко, І. В. Карась; Харк. нац. акад. міськ. госп-ва - Х.: ХНАМГ, 2012, - 323 с.

7. https://www.ti.com/lit/ds/symlink/lmr14030.pdf

8. http://ww1.microchip.com/downloads/en/DeviceDoc/Atmel-7810-AutomotiveMicrocontrollers-ATmega328P_Datasheet.pdf

Завальський В.I., маг., Чуйко М.М., к.т.н.

Івано-Франківський національний технічний університет нафти і газу

\section{КОНТРОЛЬ КРАЙОВОГО КУТА ЗМОЧУВАННЯ ПРИПОЇВ ДЛЯ ПІДВИЩЕННЯ ЯКОСТІ ПРОЦЕСУ ПАЯННЯ}

Стаття присвячена контролю якості паяльних матеріалів на основі визначення крайового кута змочування припоєм основного матеріалу паяння. Широкий вибір паяльних матеріалів дозволяє здійснювати підбір припою з оптимальними властивостями, щзо забезпечують високу змочуваність та міцність механічного з'єднання частин деталей. Висока якість процесу паяння може бути досягнена при правильному виборі необхідних паяльних матеріалів. Оскільки змочування визначає подальший характер зв'язку між припоєм та основним матеріалом паяння, тому вимірювання саме крайового кута змочування покладено в основу контролю якості паяльних матеріалів, за умови дотримання основних вимог технологічного процесу. Безпосереднє визначення значення крайового кута змочування здійснюеться опосередкованим методом лежачої краплі, иляхом вимірювання основних параметрів краплі за допомогою інфрачервоних перетворювачів. Використання IЧ випромінювача дозволяє отримувати вимірювальний сигнал у вигляді цифрового коду, який в свою чергу інтерпретується у висоту краплі припою, на основі якої і здійснюється визначення ККЗ припою. Менше значення крайового кута змочування відповідає крашій взаємодії матеріалів, а значить і більи якісному електричному контакту.

Ключові слова: припій, змочування, крайовий кут змочування, контроль, якість.

Завальський В.И., маг., Чуйко М.М., к.т.н.

Ивано-Франковський национальный технический университет нефти и газа

\section{КОНТРОЛЬ КРАЕВОГО УГЛА СМАЧИВАНИЯ ПРИПОЕМ ДЛЯ ПОВЫШЕНИЯ КАЧЕСТВА ПРОЦЕССА ПАЙКИ}

Статья посвящена контролю качества паяльных материалов на основе определения краевого угла смачивания припоем основного материала пайки. Широкий выбор паяльных материалов позволяет осуществлять подбор припоя с оптимальньми свойствами, обеспечиваюшими высокую смачиваемость и прочность механического соединения частей деталей. Высокое качество проиесса пайки может быть достигнута при правильном выборе необходимых паяльных материалов. Поскольку смачивания определяет дальнейший характер связи между припоем и основным материалом пайки, поэтому измерение именно краевого угла смачивания положен в основу контроля качества паяльных материалов, при условии соблюдения основных требований технологического процесса. Непосредственное определение значения краевого угла смачивания осуществляется косвенныл методом лежащей капли, путем измерения основных параметров капли с помощью инфракрасных преобразователей. Использование ИК излучателя позволяет получать измерительный сигнал в виде цифрового кода, который в свою очередь интерпретируется в высоту капли припоя, на основе которой и осуществляется определение ККЗ припоя. Меньшее значение краевого угла смачивания соответствует лучшему взаимодействию материалов, а значит и более качественному электрическому контакту.

Ключевые слова: припой, смачивания, краевой угол смачивания, контроль, качество. 